\title{
PERFORMA KUANTITATIF SAPI PERANAKAN ONGOLE PASCA SAPIH DI SENTRA PETERNAKAN RAKYAT MAJU SEJAHTERA KABUPATEN LAMPUNG SELATAN
}

\author{
M.D.I. HAMDANI ${ }^{1}$, A. HUSNI ${ }^{1}$ DAN A. SETYAWAN ${ }^{1}$ \\ ${ }^{1}$ Department of Animal Husbandry, Faculty of Agriculture, Lampung University \\ Prof. Soemantri Brojonegoro Street No.1 Gedongmeneng, Bandar Lampung 35145 \\ Telp (0721) 701583 \\ E-mail: agussuratmi@gmail.com
}

\begin{abstract}
The research was conducted with the aim to know the quantitative performance of post-wean PO cattle in SPR Maju Sejahtera Tanjungsari District, South Lampung Regency. The observation was conducted on PO cattle in each group member. The sample of observation was determined by purposive sampling. The survey method used in this study was conducted from October to November 2017. The observed variables were quantitative performance (body length, height, chest circumference, and body weight) PO cattle in age group P1 (>12-24 months) and P2 (>24-36 months). The result of the observation was analyzed by descriptive method. The results showed that the average quantitative performance of PO

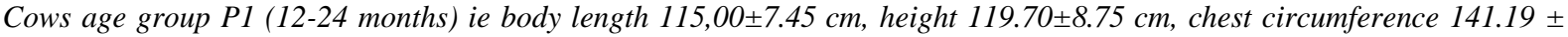
$5.62 \mathrm{~cm}$, and body weight 177,66 $21,39 \mathrm{~kg}$. Average quantitative performance PO cows age group P2 (24-36 months) ie

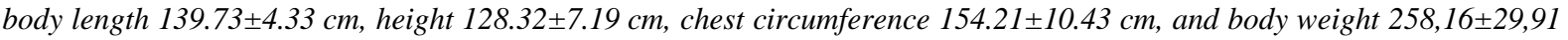
$\mathrm{kg}$.
\end{abstract}

Keywords: $P O$ cattle, quantitative performance, sentra peternakan rakyat

\section{PENDAHULUAN}

Daging adalah salah satu produk peternakan yang merupakan sumber protein hewani yang dibutuhkan oleh tubuh. Sampai saat ini permintaan daging terus mengalami peningkatan dari tahun ke tahun, hal ini sejalan dengan peningkatan jumlah penduduk.

Produksi daging nasional belum mampu mengimbangi permintaan konsumen di dalam negeri. Salah satu upaya untuk mememenuhi kebutuhan daging sapi tersebut adalah dengan meningkatkan populasi sapi potong.

Sapi Peranakan Ongole (PO) adalah salah satu sapi lokal yang banyak dibudidayakan di Indonesia (Astuti, 2004). Sapi PO disukai oleh peternak karena memiliki tingkat keberhasilan kebuntingan yang lebih baik dibandingkan dengan sapi keturunan sub tropis (Subiharta $e t$ al. 2013). Sapi PO banyak dipelihara masyarakat Kecamatan Tanjungsari, Kabupaten Lampung Selatan terutama wilayah yang pada 2015 -- 2016 ditetapkan sebagai Sentra Peternakan Rakyat (SPR) dengan nama SPR Maju Sejahtera.

SPR merupakan suatu kawasan yang ditetapkan sebagai media pembangunan peternakan dan kesehatan hewan yang di dalamnya terdapat populasi ternak sapi yang dimiliki oleh sebagian besar pemukim di satu desa atau lebih, serta sumber daya alam untuk kebutuhan hidup ternak (air dan bahan pakan). Di dalam SPR terdapat suatu kegiatan Sekolah Peternakan Rakyat (Sekolah PR) yang merupakan sarana transfer ilmu pengetahuan dan teknologi untuk membangun kesadaran peternak dan mendorong tindakan kolektif (Dirjen Peternakan dan Kesehatan Hewan, 2015).

SPR di Provinsi Lampung yang mengalami perkembangan yang cukup baik terdapat di Kecamatan Tanjungsari, Kabupaten Lampung Selatan. SPR Maju Sejahtera Kecamatan Tanjungsari, Kabupaten Lampung Selatan.

SPR di Provinsi Lampung memberikan dampak yang positif bagi peningkatan produktivitas sapi PO yang dapat terlihat dari performa kuantitatif yang ditunjukan oleh ternak. Performa kuantitatif adalah hal yang penting dalam melihat tingkat produktifitas ternak . Performa kuantitatif meliputi panjang badan, tinggi badan, lingkat dada, dan bobot badan.

Sampai sejauh ini belum ada penelitian mengenai bagaimana produktifitas ternak yang dihasilkan oleh Sapi PO jantan yang ada di SPR Maju Sejahtera. Oleh sebab itu perlu adanya penelitian mengenai sejauh mana 
performa kuantitatif sapi PO jantan yang ada di wilayah SPR tersebut.

\section{MATERI DAN METODE}

\section{Materi}

Materi penelitian terdiri dari sapi PO jantan di SPR Maju Sejahtera Kecamatan Tanjungsari Kabupaten Lampung Selatan dari berbagai umur yaitu Poel 1 (P1) yaitu umur ternak 1224 bulan dengan jumlah ternak 57 ekor dan Poel 2 (P2) yaitu umur ternak 24-36 bulan dengan jumlah ternak 19 ekor. Alat yang digunakan dalam penelitian ini adalah timbangan ternak merk Sonic A12E kapasitas 5 ton, pita ukur merk rondo dengan ketelitian $0,1 \mathrm{~cm}$, tongkat ukur, alat tulis, dan kamera.

\section{Metode}

Penelitian dilakukan dengan metode survey dan penentuan sampel dilakukan dengan purposive sampling. Materi yang diamati berupa Sapi PO jantan dari berbagai umur. Peubah yang diamati terdiri dari performa kuantitatif seperti bobot badan, lingkar dada, panjang badan, dan tinggi badan. Data performa kuantitatif dianalisis secara deskriptif.

\section{HASIL DAN PEMBAHASAN}

\section{Performa Kuantitatif Sapi PO Kelompok Umur P1 (>12-24 bulan) di SPR Maju Sejahtera}

Rataan ukuran tubuh (Tabel 1) Sapi PO kelompok umur P1 memiliki panjang badan $115,00 \pm 7,45 \mathrm{~cm}$, tinggi badan $119,70 \pm 8,75$ $\mathrm{cm}$, lingkar dada 141,19 $\pm 5,62 \mathrm{~cm}$, dan bobot badan 177,66 $\pm 21,39 \mathrm{~kg}$. Hasil tersebut menunjukan bahwa sapi PO kelompok umur P1 memiliki kualitas yang kurang baik jika dibandingkan dengan Standar Nasional Indonesia (SNI) kelas III untuk umur 12-24 tahun yang memunyai panjang badan $124 \mathrm{~cm}$, tinggi badan $122 \mathrm{~cm}$, lingkar dada $144 \mathrm{~cm}$ (SNI, 2015). Hal ini dikarenakan faktor pemberian pakan dan manajemen pemeliharaan pada ternak. Pada sistem pemeliharaannya Sapi PO di SPR Maju sejahtera dipelihara secara sistem pemeliharaan semi intensif yaitu tenak dikandangkan pada malam hari dan dilepas di ladang penggembalaan pada pagi (Hernowo, 2006). Sapi PO digembalakan di perkebunan milik PT Perkebunan Nusantara 7 (PTPN 7) yang merupakan salahsatu Perusahaan Badan Usaha Milik Negara (BUMN) yang ada di Provinsi Lampung.

Tabel 1. Performa kuantitatif Sapi PO kelompok umur P1 di SPR Maju Sejahtera

\begin{tabular}{|c|c|c|c|c|c|}
\hline \multirow[b]{2}{*}{ No } & \multirow[b]{2}{*}{ Desa } & \multicolumn{4}{|c|}{ Peubah yang diamati } \\
\hline & & $\begin{array}{c}\text { Panjang Badan } \\
(\mathrm{cm})\end{array}$ & $\begin{array}{l}\text { Tinggi Badan } \\
(\mathrm{cm})\end{array}$ & $\begin{array}{c}\text { Lingkar Dada } \\
(\mathrm{cm})\end{array}$ & $\begin{array}{c}\text { Bobot Badan } \\
(\mathrm{kg})\end{array}$ \\
\hline 1 & Wawasan & $118,57 \pm 9,50$ & $125,29 \pm 11,51$ & $137,43 \pm 5,80$ & $187,14 \pm 15,87$ \\
\hline 2 & Bangunsari & $106,00 \pm 1,00$ & $115,00 \pm 1,00$ & $151,00 \pm 1,00$ & $221,00 \pm 1,00$ \\
\hline 3 & Sidomukti & $123,25 \pm 13,45$ & $122,63 \pm 8,11$ & $147,25 \pm 4,20$ & $198,25 \pm 36,20$ \\
\hline 4 & Kertosari & $115,17 \pm 6,34$ & $120,17 \pm 9,45$ & $132,83 \pm 8,45$ & $120,17 \pm 9,45$ \\
\hline 5 & Purwodadi Dalam & $114,44 \pm 11,34$ & $122,63 \pm 14,26$ & $143,75 \pm 7,41$ & $188,06 \pm 34,56$ \\
\hline 6 & Wonodadi & $113,24 \pm 8,40$ & $114,24 \pm 12,70$ & $137,12 \pm 9,66$ & $161,53 \pm 26,96$ \\
\hline \multirow[t]{2}{*}{7} & Malangsari & $114,50 \pm 2,12$ & $118,00 \pm 4,24$ & $139,00 \pm 2,83$ & $167,5 \pm 14,85$ \\
\hline & Rata-rata & $115,00 \pm 7,45$ & $119,70 \pm 8,75$ & $141,19 \pm 5,62$ & $177,66 \pm 21,39$ \\
\hline $\begin{array}{l}\mathrm{Pa} \\
\text { berup } \\
\text { perke } \\
\text { hijaua }\end{array}$ & $\begin{array}{l}\text { yang diperoleh } \\
\text { Imput yang tum } \\
\text { an karet. Rump } \\
\text { ang sudah umum }\end{array}$ & $\begin{array}{l}\text { lebih banyak } \\
\text { bawah lahan } \\
\text { ng merupakan } \\
\text { akan oleh para }\end{array}$ & \multicolumn{3}{|c|}{$\begin{array}{l}\text { dibudidayakan. Rumput lapang merupakan } \\
\text { campuran dari berbagai rumput lokal yang } \\
\text { umumnya tumbuh secara alami dengan daya } \\
\text { produksi dan kualitas nutrisi yang rendah } \\
\text { karena itu rumput lapang memiliki kualitas } \\
\text { yang rendah untuk pakan ternak (Prasetya, } \\
\text { 2011). }\end{array}$} \\
\hline
\end{tabular}
peternak sebagai pakan utama ternak ruminansia untuk memenuhi kebutuhan serat kasar. Rumput ini mudah diperoleh, murah dan mudah dikelola karena tumbuh liar tanpa
Selain dari rumput saat penggembalaan, beberapa peternak juga memberikan pakan tambahan berupa limbah-limbah pertanian 
seperti jerami, daun singkong, dan tebon jagung serta rumput potong yang sengaja di peliara seperti rumput gajah dan setaria. Untuk pakan berupa limbah agroindustri hanya beberapa peternak yang memberikan seperti kelompok ternak yang ada di Wawasan, Purwodadi Dalam, dan Sidomukti. Pakan tambahan yang diberikan berupa ampas tahu,onggok dan dedak padi. Jenis pakan yang diberikan belum mampu memenuhi nutrisi bagi ternak sehingga performa kuantitatif sapi PO juga kurang optimal. Potensi pertumbuhan ini dipengaruhi oleh faktor individu ternak dan jenis pakan. Tillman et al. (1998) menyebutkan bahwa faktor pakan sangat menentukan pertumbuhan, bila kualitasnya baik dan diberikan dalam jumlah yang cukup, pertumbuhannya akan menjadi cepat, demikian pula sebaliknya.

Faktor genetik juga sangat memengaruhi performa ternak, performa ternak sapi PO pada P1 yang kurang baik dapat disebabkan proses seleksi tetua yang unggul pada SPR Maju Sejahtera belum maksimal, sehingga keturunan yang dihasilkan juga belum menunjukkan performa yang baik. Hal ini sesuai dengan Hardjosubroto (1994) yang menyatakan bahwa ternak yang memunyai mutu genetik yang unggul akan mewariskan sifat tersebut kepada keturunannya.

\section{Performa Kuantitatif Sapi PO Kelompok Umur P2 (>24-35 bulan) di SPR Maju Sejahtera}

Berdasarkan data yang diperoleh dari hasil penelitian, rata-rata performa kuantitatif Sapi PO kelompok umur P2 (Tabel 2) di SPR Maju Sejahtera yaitu panjang badan 139,73 $\pm 4,33$ $\mathrm{cm}$, tinggi badan $128,32 \pm 7,19 \mathrm{~cm}$, lingkar dada
$154,21 \pm 10,43 \mathrm{~cm}$, dan bobot badan $258,16 \pm 29,91 \mathrm{~kg}$. Hasil rata-rata performa tersebut, Sapi PO di SPR Maju Sejahtera secara garis besar masuk kedalam kelas III menurut SNI 7651.5:2015 dengan rataan panjang badan masuk dalam kelas I. Sapi PO jantan kelompok umur P2 tergolong memiliki performa yang cukup baik. Tampilan performa juga dipengaruhi oleh faktor genetik dan lingkungan termasuk lingkungan pakan dan kesehatan. Hal ini diperkuat oleh pendapat Hardjosubroto (1994) yang mengatakan bahwa, penampilan sifat kuantitatif dipengaruhi oleh faktor genetik dan lingkungan, serta kadang-kadang ditemukan pengaruh interaksi keduanya (genetik dan lingkungan). Selain itu, Trifena et al (2011), berpendapat bahwa sifat kuantitatif pada sapi sangat dipengaruhi oleh lingkungan diantaranya dari segi manajemen pemeliharaan dan pemberian pakan.

Faktor lain yang diduga mempengaruhi ukuran tubuh Sapi PO adalah faktor genetik yang diturunkan oleh tetua terutama pejantan. Sistem perkembangbiakan di SPR Maju Sejahtera sudah cukup baik yaitu menggunakan metode Inseminasi Buatan (IB). Metode IB menggunakan semen beku hasil dari pejantan-pejantan unggul yang telah dikembangkan sehingga sifat-sifat yang baik dari pejantan unggul tersebut dapat diturunkan kepada keturunan hasil dari IB. Selain itu IB terhitung tidak terlalu mahal bagi masyarakat yaitu untuk satu kali IB membayar Rp. $80.000,00$ dan untuk biaya IB selanjutnya membaya Rp. 50.000,00 sehingga sangat diminati oleh peternak. Sesuai dengan pendapat Warwick et al. (1990), bahwa sifat yang secara genetik menurun pada keturunanya , terutama adalah sifat yang diturunkan oleh pejantan.

Tabel 2. Performa kuantitatif Sapi PO kelompok umur P2 di SPR Maju Sejahtera

\begin{tabular}{llrrrr}
\hline & & \multicolumn{4}{c}{ Peubah yang diamati } \\
\cline { 3 - 6 } No & & \multicolumn{1}{c}{$\begin{array}{c}\text { Panjang Badan } \\
(\mathrm{cm})\end{array}$} & $\begin{array}{c}\text { Tinggi Badan } \\
(\mathrm{cm})\end{array}$ & $\begin{array}{c}\text { Lingkar Dada } \\
(\mathrm{cm})\end{array}$ & $\begin{array}{r}\text { Bobot Badan } \\
(\mathrm{kg})\end{array}$ \\
\hline 1 & Wawasan & $129,40 \pm 10,14$ & $131,00 \pm 7,81$ & $152,6 \pm 12,56$ & $227,4 \pm 64,19$ \\
2 & Bangunsari & $146,00 \pm 1,00$ & $120,00 \pm 1,00$ & $150,00 \pm 1,00$ & $251,00 \pm 1,00$ \\
3 & Sidomukti & $140,50 \pm 2,45$ & $131,25 \pm 4,86$ & $167,00 \pm 26,01$ & $286,75 \pm 79,09$ \\
4 & Kertosari & $129,50 \pm 10,01$ & $131,67 \pm 25,69$ & $153,17 \pm 11,60$ & $245,83 \pm 25,69$ \\
5 & Purwodadi Dalam & $143,00 \pm 1,41$ & $134,00 \pm 2,83$ & $152,50 \pm 0,71$ & $276,00 \pm 8,49$ \\
6 & Wonodadi & - & - & - & - \\
7 & Malangsari & $150,00 \pm 1,00$ & $122,00 \pm 1,00$ & $150,00 \pm 1,00$ & $262,00 \pm 1,00$ \\
\hline & Rata-rata & $139,73 \pm 4,33$ & $128,32 \pm 7,19$ & $154,21 \pm 10,43$ & $258,16 \pm 29,91$ \\
\hline
\end{tabular}




\section{Pola Pertumbuhan Sapi PO di SPR Maju Sejahtera}

Berdasarkan Gambar 1, grafik pertumbuhan performa kuantitatif Sapi PO mengalami peningkatan ukuran tubuh. Peningkatan performa terlihat sangat signifikan pada ratarata bobot badan. Peningkatan rata-rata bobot badan dari P1 sampai P2 diduga disebabkan oleh bangsa sapi dan umur ternak yang diduga tidak memiliki keseragaman. Pertumbuhan tubuh ternak di periode pertama ternak sedang melewati fase linier atau pertumbuhan yang sangat cepat dengan waktu yang sangat pendek (Lawrence dan Fowler, 2002).



Gambar 1. Grafik Pola pertumbuhan Sapi PO jantan

Bobot badan yang didapat pada penelitian ini memiliki nilai rata-rata yang normal bagi pertumbuhan sapi PO yang terlihat pada kelompok umur P2 yaitu $258,16 \pm 29,91 \mathrm{~kg}$, hal ini sesuai dengan pendapat Hastuti (2002) menyatakan bahwa rata-rata bobot badan sapi PO umur 1,5-2 tahun berkisar antara 250-300 $\mathrm{kg}$ dan rata-rata bobot badan sapi PO jantan umur 2-3 tahun yaitu 201-366 kg. Menurut Soeroso (2004) lingkar dada selalu menjadi parameter bobot badan tiap persamaan pendugaan bobot badan, bahkan menjadi parameter utama.

Pada grafik panjang badan, tinggi badan dan lingkar dada Sapi PO menunjukan peningkatan namun tidak seperti bobot badan. Menurut Diwyanto (1982) pengaruh panjang badan terhadap bobot badan relatif rendah dan pertumbuhan ternak pada umumnya mengarah samping lebih signifikan dan terlihat sangat nyata bersamaan dengan bertambahnya umur. Sehingga umur sapi yang lebih tua memiliki panjang badan yang lebih besar.

\section{KESIMPULAN}

Berdasarkan hasil penelitian dapat disimpulkan bahwa

1. Nilai rata-rata performa kuantitatif Sapi PO jantan di SPR Maju Sejahtera kelompok umur P1 (12-24 bulan) yaitu panjang badan $115,00 \pm 7,45 \mathrm{~cm}$, tinggi badan $119,70 \pm 8,75$ $\mathrm{cm}$, lingkar dada $141,19 \pm 5,62 \mathrm{~cm}$, dan bobot badan $177,66 \pm 21,39 \mathrm{~kg}$.

2. Nilai rata-rata performa kuantitatif Sapi PO jantan di SPR Maju Sejahtera kelompok umur P2 (24-36 bulan) yaitu panjang badan $139,73 \pm 4,33 \mathrm{~cm}$, tinggi badan $128,32 \pm 7,19$ $\mathrm{cm}$, lingkar dada $154,21 \pm 10,43 \mathrm{~cm}$, dan bobot badan $258,16 \pm 29,91 \mathrm{~kg}$.

3. Sapi PO di SPR Maju Sejahtera mengalami peningkatan performa kuantitatif pada 2 tahap kelompok umur, Peningkatan performa paling tinggi terjadi pada bobot badan dan 3 performa lain yaitu panjang badan, tinggi badan dan lingkar dada mengalami peningkatan namun tidak begitu tinggi.

\section{DAFTAR PUSTAKA}

Astuti, M. 2004. Potensi dan Keragaman Sumberdaya Genetik Sapi Peranakan Ongole (PO). Lokakarya Nasional Sapi Potong 2004. Fakultas Peternakan. Universitas Gadjah Mada. Yogyakarta.

Direktorat Jenderal Peternakan Dan Kesehatan Hewan Kementerian Pertanian Republik Indonesia. 2015. Pedoman Sentra Peternakan Rakyat (SPR). Jakarta. 
Diwyanto, K. 1982 Pengamatan Fenotip Domba Priangan Serta Hubungan Antara Beberapa Ukuran Tubuh Dengan Bobot Badan. Tesis. Program Pasca Sarjana Institut Pertanian Bogor, Bogor.

Hardjosubroto, W. 1994. Aplikasi Pemuliabiakan Ternak di Lapangan. PT Grasindo. Jakarta.

Hastuti, M. 2002. Kinerja Sapi Peranakan Ongole Jantan yang Disuplementasi Bioplus. Skripsi. Fakultas Peternakan Universitas Gadjah Mada. Yogyakarta.

Hernowo, B. 2006. Prospek Pengembangan Usaha Peternakan Sapi Potong di Kecamatan Surade Kabupaten Sukabumi. Skripsi. Program Studi Sosial Ekonomi Peternakan. Fakultas Peternakan. Institut Pertanian Bogor, Bogor.

Lawrence T.L.J. dan V.R. Fowler. 2002. Growth of Farm Animals. 2nd Ed. CABI Publishing, London.

Prasetya, A. 2011. Manajemen Pemeliharaan Sapi Potong pada Peternakan Rakyat di Sekitar Kebun Percobaan Rambatan BPTP Sumatera Barat. Departemen Ilmu Produksi dan Teknologi Peternakan. Skripsi. Fakultas Peternakan Institut Pertanian Bogor. Bogor.

Soeroso, 2004. Performans Sapi Jawa Berdasarkan Sifat Kuantitatif dan Kualitatif. Tesis.
Program Pascasarjana. Universitas Diponegoro, Semarang.

Standar Nasional Indonesia. 2015. Bibit Sapi Potong Peranakan Ongole SNI 7651.5:2015. Badan Standardisasi Nasional.

Subiharta, Muryanto, dan B. Utomo. 2013. Laporan Kegiatan Pendampingan PSDS Melalui Inovasi Teknologi dan Kelembagaan Untuk Peningkatan Produksi Daging di Jawa Tengah. Balai Pengkajian Teknologi Pertanian Jawa Tengah, Semarang.

Tillman, A. D., H. Hartadi, S. Reksohadiprodjo, S. Prawirokusumo, dan S. Lebdosoekojo. 1998. Ilmu Makanan Ternak Dasar. Gadjah Mada University Press, Yogyakarta.

Trifena, Budisatria, I.G.S. dan T. Hartatik. 2011. Perubahan Fenotip Sapi Peranakan Ongole, Simpo, dan Limpo pada Keturunan Pertama dan Keturunan Kedua (Backcross). Fakultas Peternakan Universitas Gadjah Mada. Yogyakarta. Buletin Peternakan, 35(1): 11-16.

Warwick, I.J., J M. Astuti dan W. Hardjosubroto. 1990. Pemuliaan Ternak. Gadjah Mada University Press. Yogyakarta. 